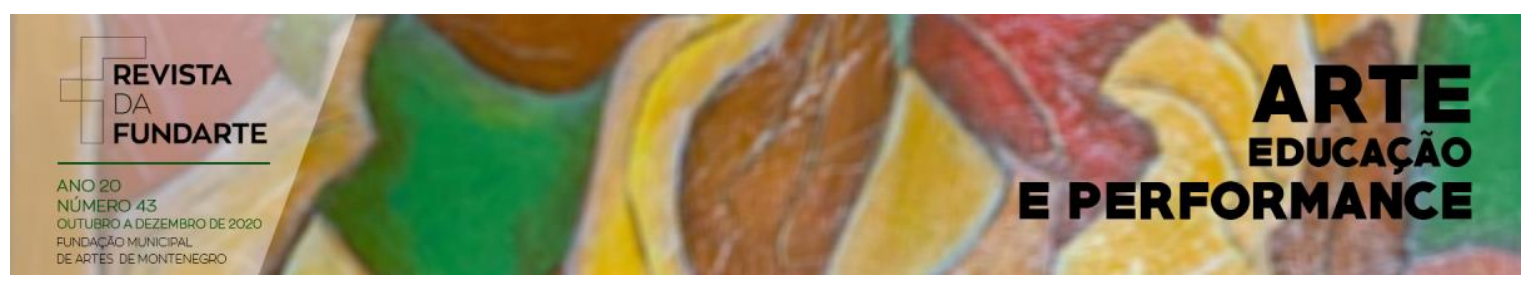

\title{
BRICOLAGENS KHAÓTICA, MEMÓRIA SOCIAL E ENGAJAMENTOS EM SR. CLANDESTINO
}

\author{
Denisson Beretta Gargione \\ Lucas Graeff \\ DOI: http://dx.doi.org/10.19179/2F2319-0868/2F733
}

GARGIONE, Denisson Beretta; GRAEFF, Lucas. Bricolagens khaótica, memória social e engajamentos em Sr. Clandestino. Revista da FUNDARTE. Montenegro, p.01-21, ano 20, ㄲo 43, outubro/dezembro de 2020.

Disponível em: http://.seer.fundarte.rs.gov.br/index.php/revistadafundarte/index $>20$ de dezembro de 2020. 


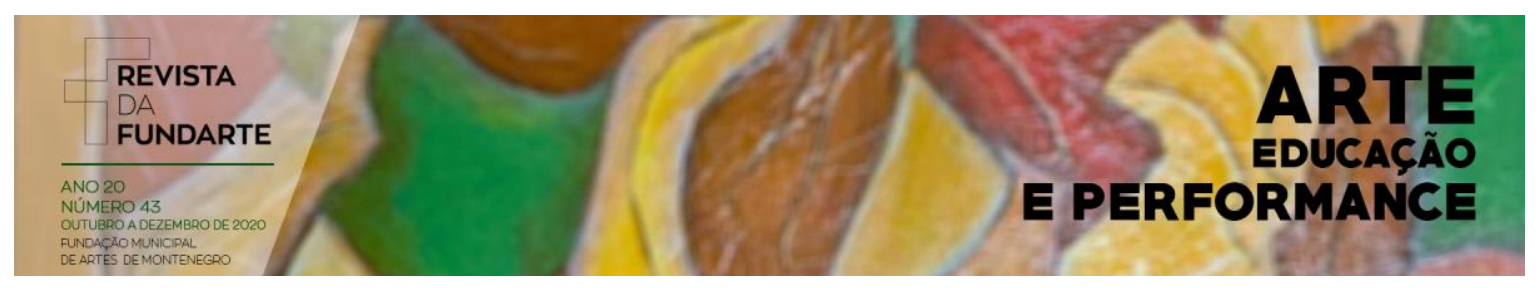

\title{
BRICOLAGENS KHAÓTICA, MEMÓRIA SOCIAL E ENGAJAMENTOS EM SR. CLANDESTINO
}

Denisson Beretta Gargione ${ }^{1}$

Lucas Graeff ${ }^{2}$

\begin{abstract}
Resumo: Este ensaio propõe reflexões e ideias sobre o processo de criação do espetáculo Sr. Clandestino, da companhia Khaos Cênica. Nele, a dramaturgia foi produzida concomitantemente com o espetáculo com vistas a promover a mobilização e a participação do público na criação da peça. Em outras palavras, as proposições da encenação nas relações entre o artista e o público ditaram o espetáculo e as alterações necessárias ao texto, não o contrário. Para dar conta conceitualmente desse processo, foram trabalhados os conceitos de memória social, bricolagem e engajamento. Como conclusão, (re)afirma-se a importância da partilha do sensível e de espaços e tempos de mediações para a criação dramatúrgica e performática.
\end{abstract}

Palavras-chave: Criação dramatúrgica; Memória social; Engajamento; Bricolagem.

\section{KHAÓTICA'S BRICOLAGES: SOCIAL MEMORY AND ENGAGEMENTS IN MR. CLANDESTINO}

Abstract: The purpose of this essay is to provide some insights into dramaturgical creation. We take as our object the play "Mr. Clandestino", produced by Khaos Cenica theater company. In this play, the dramaturgy was produced together with the performance in order to promote the mobilization and participation of the public. In other words, the interactions between the artist and the public determined the performance and the dramaturgy. The conceptual approach is based on the concepts of social memory, bricolage and engagement. As conclusion, we defend the importance of shared sensitivities and creative interactions in the dramaturgical and performative processes.

Keywords: Dramaturgical creation; Social memory; Engagement; Bricolage.

\footnotetext{
${ }_{1}^{1}$ Ator, produtor, autor de peças teatrais, diretor de espetáculos de teatro e dança, pesquisador nas áreas de economia da cultura, desenvolve pesquisa nas áreas de dramaturgia do espetáculo, o trabalho de ator da Commedia DellArte e o hibridismo de linguagens.Em 2010 fundou com Lauren Hartz a Companhia KHAOS Cênica, realizando os espetáculos Sereia Bailarina das Águas, (2011, Prêmio Açorianos de melhor figurino e Indicação de melhor produção), como bailarino e produtor, $O$ Inspetor Geral (Prêmio Funarte de Teatro Myriam Muniz 2013), como ator e produtor, RubroAlmodóvar (Financiando pelo Fumproarte, 2016), como diretor, bailarino e produtor, O Circo Chegou: El Grand Scaramouche (Prêmio Empreendedor Cultural, 2016) além do programa Commedia Del Lavoro, que pesquisa o gênero da Commedia DellArte e o traduz para o teatro empresa em pequenas peças voltadas ao universo coorporativo.

2 Doutor em Etnologia e Sociologia Comparada pela Université Rene Descartes (Paris V, Sorbonne) e bolsista de produtividade do CNPq (Nível 2). Desde 2017, é Coordenador do Programa de PósGraduação em Memória Social e Bens Culturais da Universidade La Salle. Atualmente, é pesquisador associado ao Laboratório PACTE (Sciences Po Grenoble) e membro do Comitê Brasileiro do Conselho Internacional de Monumentos e Sítios (ICOMOS-BRASIL), do Conselho Científico de OpenEditions.org (Electronic resources in the humanities and social sciences) e da Rede IPOPsAgeS, vinculada ao Institut National d'Études Demographiques (INED-França).
}

GARGIONE, Denisson Beretta; GRAEFF, Lucas. Bricolagens khaótica, memória social e engajamentos em Sr. Clandestino. Revista da FUNDARTE. Montenegro, p.01-21, ano 20, ㄲo 43, outubro/dezembro de 2020.

Disponível em: http://.seer.fundarte.rs.gov.br/index.php/revistadafundarte/index $>20$ de dezembro de 2020. 


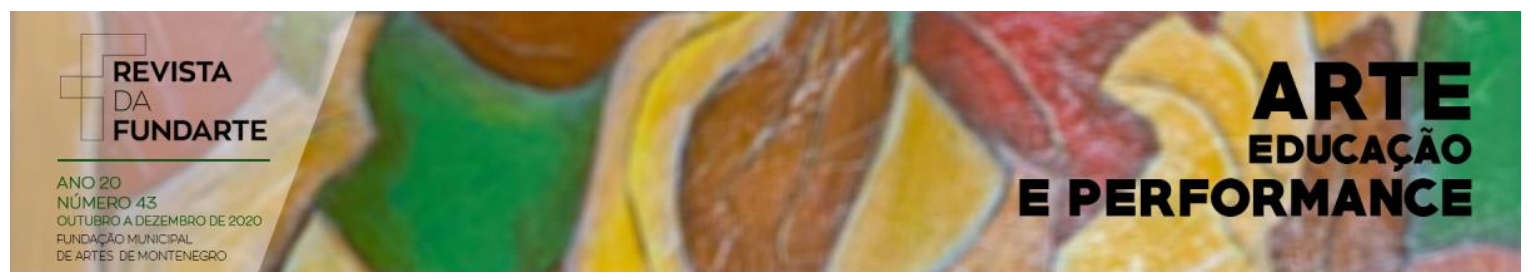

\section{INTRODUÇÃO}

Este ensaio propõe reflexões e ideias sobre o processo de criação dramatúrgica do espetáculo Sr. Clandestino, da companhia Khaos Cênica. Neste processo, tomamos como norte o anseio de criar e compartilhar métodos de trabalho promovendo a mobilização e compreensão das relações entre os artistas, o espetáculo e seus diferentes públicos. Estivemos no epicentro de uma espécie de "persquisa-ação" que não buscava resolver um "problema" em particular, mas responder ao desejo de criar uma peça teatral a partir de duas palavras-chave que descobrimos e das quais nos reapropriamos ao longo da caminhada: engajamento e bricolagem.

Por engajamento, compreendemos a efetiva adesão situacional do público ao espetáculo (GRAEFF, 2019). Pode referir-se desde ao impulso de cantarolar uma cena junto a um espetáculo, quanto a aplaudi-lo em cena aberta, ou até mesmo vaiá-lo. O público reage espontaneamente à obra, mas também toma-a para si, estética e emocionalmente - nem que isso se dê pela rejeição ou aversão. Quanto à "bricolagem", nós a pensamos como um trabalho manual-criativo de improvisação. $\mathrm{Na}$ elaboração de espetáculos em companhias de teatro como a Khaos Cênica, há um acúmulo de funções que impõe a seus realizadores a responsabilidade de operar em inúmeras frentes. Isso promove "bricolagens" no sentido de que buscamos, com nossas próprias mãos e capacidades criativas, técnicas e tecnologias que exigem de nós um aprendizado "do-it-yourself", mas orientado para uma apresentação profissional.

Porém, a dialética entre bricolagem e engajamento que movimentou a criação do espetáculo Sr. Clandestino se desdobrou em um campo que não é estranho ao teatro e à dramaturgia, mas que nem sempre é nomeado nesses termos: memória social. Em que consiste esse campo? Nós entendemos que a memória social é, antes de tudo, a interface entre o sujeito e o mundo; em seguida, que é "a busca incessante - e existencialmente recomeçada a cada reconstrução inventiva e intempestiva de sentidos - [de] causalidades formais e materiais - que se oferece aos divertimentos da linguagem e da imaginação humanas" (GRAEFF, 2016, p.

GARGIONE, Denisson Beretta; GRAEFF, Lucas. Bricolagens khaótica, memória social e engajamentos em Sr. Clandestino. Revista da FUNDARTE. Montenegro, p.01-21, ano 20, ㄲo 43, outubro/dezembro de 2020.

Disponível em: http://.seer.fundarte.rs.gov.br/index.php/revistadafundarte/index $>20$ de dezembro de 2020. 


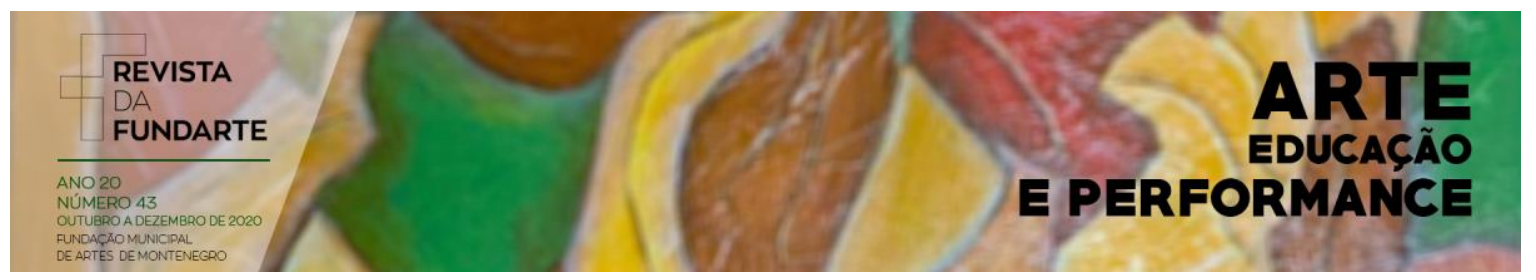

184). Ao nosso ver, as relações dialéticas entre bricolagem e engajamento são potencialmente uma expressão da memória social e, ao mesmo tempo, geradoras de uma experiência comum. Como o poeta Fernando Pessoa escreve, "A memória é a consciência inscrita no tempo". É desta consciência que trata as "correntezas de memória coletiva" (HALBWACHS, 2006); correntezas que circulam nas consciências individuais de um grupo diante de um espetáculo e que, quando engajadas, configuram-se como uma "crônica estética" que se articula com a criação artística.

\section{BRICOLAGENS KHAÓTICAS E CANOVACCIOS SOBRE UM ANTI-HERÓI CLANDESTINO}

A base do processo criativo gerador de Sr. Clandestino partiu do texto, da dramaturgia do espetáculo. Contudo, antes de ser uma elaboração tradicional - o que no passado recente do teatro poderia ser conhecido como uma ditadura do texto -, para nós, o texto está a serviço da cena. Essa concepção da dramaturgia é própria dos trabalhos da Companhia KHAOS Cênica, consistindo em elaborar o texto enquanto a cena é constituída. Nesse sentido, as proposições da encenação ditam o espetáculo e as alterações necessárias ao texto, não o contrário. Isso torna o texto vivo e passível de tantas adaptações constantes quanto forem necessárias.

A inspiração inicial para a dramaturgia de Sr. Clandestino surgiu em O Guia Definitivo do Mochileiro das Galáxias (2016), Douglas Adams. O tom anárquico do livro, somado a crítica social e comédia cientificista, com um distanciamento antropológico, eram proposições bastante sedutoras para nós. Em especial o personagem presente no livro, chamado Zaphod Beeblebrox, com seu caráter amoral e irresponsável, o que nos pareceu um ponto de referência interessante para o espectador, capaz de construir um distanciamento racional e consciente sobre os fatos, ao mesmo tempo em que estabelece empatia.

Para nós, Sr. Clandestino seria um anti-herói. De acordo com Campbell, o herói na autossuperação de sua condição, motivado por suas virtudes altruístas:

Mesmo nos romances populares, o protagonista é um herói ou uma heroína que descobriu ou realizou alguma coisa além do nível normal de realizações

GARGIONE, Denisson Beretta; GRAEFF, Lucas. Bricolagens khaótica, memória social e engajamentos em Sr. Clandestino. Revista da FUNDARTE. Montenegro, p.01-21, ano 20, № 43, outubro/dezembro de 2020.

Disponível em: http://.seer.fundarte.rs.gov.br/index.php/revistadafundarte/index $>20$ de dezembro de 2020. 


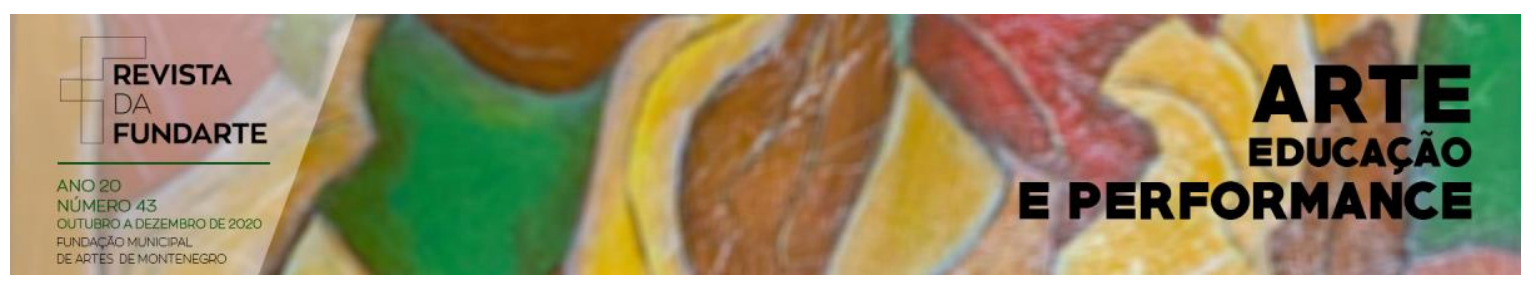

ou de experiência. O herói é alguém que deu a própria vida por algo maior que ele mesmo. [...] há dois tipos de proeza. Uma é a proeza física, em que o herói pratica um ato de coragem, durante a batalha, ou salva uma vida. $\mathrm{O}$ outro tipo é a proeza espiritual, na qual o herói aprende a lidar com o nível superior da vida espiritual humana e retorna com uma mensagem. (CAMPBELL, 1990, p. 137).

Essa elaboração de Campbell, estabelecida a partir de narrativas míticas, afirma que há uma base comum na estrutura de todas as histórias, desde a obra do poeta Homero até os blockbusters do cinema hollywoodiano. Entretanto, por mais que nós dialogássemos com estes elementos da narratologia proposta por Campbell, perguntávamo-nos sobre a antítese do herói. E foi no artigo de Mitchell (2013) que encontramos o alicerce de nossa construção:

\begin{abstract}
O "anti-herói" (também conhecido como o herói defeituoso) é um arquétipo de caráter comum para o antagonista que existe desde as comédias e tragédias do teatro grego. Ao contrário do herói tradicional, que é moralmente correto e firme, o anti-herói geralmente tem um caráter moral imperfeito. Os comprometimentos morais que ele ou ela faz muitas vezes podem ser vistos como os meios desagradáveis para um fim apropriadamente desejado - como quebrar o dedo para obter respostas - o que for preciso para o protagonista chegar à justiça. Outras vezes, no entanto, as falhas morais são simplesmente falhas morais, como o alcoolismo, a infidelidade ou um temperamento incontrolável e violento. (MITCHELL, 2013, s/p, tradução nossa ${ }^{3}$ ).
\end{abstract}

Comparativamente, o anti-herói apresenta uma vulnerabilidade moral que o herói não possui. Apesar de o herói ser uma figura de celebração e exemplar, é a partir da identificação do público com as suas vulnerabilidades que a empatia é possível. Este ponto, a nosso ver, era fundamental para provocar o engajamento do público. Assim, a empatia com o personagem principal, não foi somente uma escolha artística que fizemos para fins dramatúrgicos, mas um instrumento para consolidar o planejamento do processo de pesquisa.

A construção da dramaturgia seria pautada, essencialmente, nesta ideia de anti-herói, com quem o público viria - esperávamos - a empatizar. Em torno dele.

\footnotetext{
${ }^{3}$ No original, The "anti-hero" (also known as the flawed hero) is a common character archetype for the antagonist that has been around since the comedies and tragedies of Greek theater. Unlike the traditional hero who is morally upright and steadfast, the anti-hero usually has a flawed moral character. The moral compromises he or she makes can often be seen as the unpleasant means to an appropriately desired end-such as breaking a finger to get answers-whatever it takes for the protagonist to come to justice. Other times, however, the moral flaws are simply moral flaws, like alcoholism, infidelity, or an uncontrollable and violent temper.
}

GARGIONE, Denisson Beretta; GRAEFF, Lucas. Bricolagens khaótica, memória social e engajamentos em Sr. Clandestino. Revista da FUNDARTE. Montenegro, p.01-21, ano 20, ㄲo 43, outubro/dezembro de 2020.

Disponível em: http://.seer.fundarte.rs.gov.br/index.php/revistadafundarte/index> 20 de dezembro de 2020. 


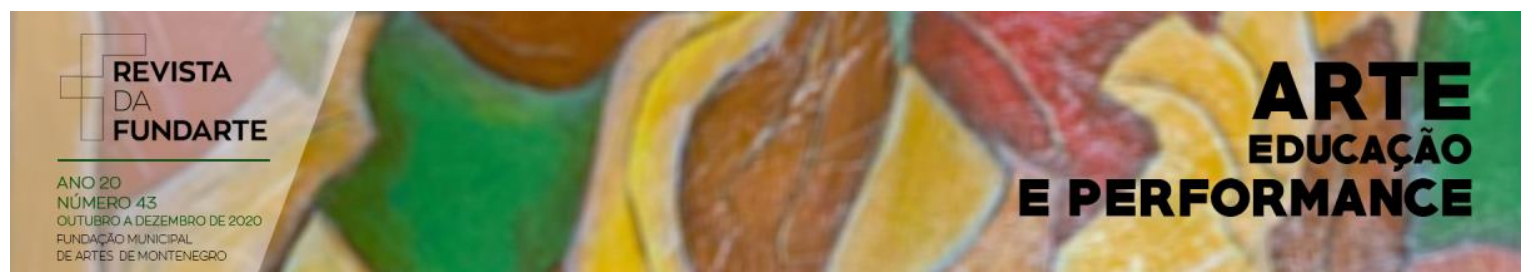

construímos o cenário e as questões fundamentais da dramaturgia. O desenho do protagonista, portanto, foi essencial para estabelecermos o modo como se daria 0 desenvolvimento da peça e suas possibilidades de desenlace.

A empatia com o nosso anti-herói foi fundante, ainda, por nossa intenção de convidar o público a decidir o rumo do espetáculo. Sob esse ponto de vista, percebemos que não dialogávamos, necessariamente, com as unidades da poética de Aristóteles (2004), ação, tempo e lugar. Em contrapartida, estabelecemos um diálogo com Brecht em seu apelo à racionalidade e a reflexão:

Eu gostaria de dizer algo breve a respeito da relação entre dramaturgia nãoaristotélica e modo científico de observação. A dramaturgia não-aristotélica de modo algum se serve da empatia [Einfühlung] do espectador (identificação - mímesis) de maneira tão inofensiva como a dramaturgia aristotélica; o modo como ela se coloca perante certos efeitos psíquicos como, por exemplo, a catarse também é substancialmente diferente. Assim como ela não pretende entregar seus heróis ao mundo como se os enviasse a seu destino inexorável, também lhe é estranho entregar o espectador a uma vivência teatral sugestiva. Ao esforçar-se em ensinar ao seu espectador um comportamento prático bem preciso, cuja finalidade é a transformação do mundo, ela já confere a ele, no teatro, uma postura fundamentalmente distinta daquela com a qual ele está acostumado: o espectador passa a ter condições de assumir uma postura crítica e controladora. Por meio desses princípios o dramaturgo abandona o ponto de vista do observador mais ou menos incontrolável; e o mundo que ele mostra pode ser tanto comparado com o mundo real quanto criticado por ele; o objetivo, portanto, é tornar o mundo, ou seja, o mundo real, manejável (praticável) para o espectador. Assim cabe à dramaturgia não-aristotélica fornecer definições praticáveis. Aquelas ciências que dizem algo a respeito da vida em sociedade devem ser aproveitadas por tal dramaturgia, inclusive para a crítica de tal dramaturgia. Esta dramaturgia e sua crítica talvez não lucrem com os resultados, por exemplo, da psicologia comportamental nãointrospectiva, mas com certeza podem lucrar com seu ponto de vista. Ela utiliza, ao menos como princípio heurístico, a dialética materialista, o único método que torna possível dizer algo a respeito do movimento das grandes massas humanas. (BRECHT, 1988, p. 168-9).

Deste modo, a dramaturgia de Sr. Clandestino tornou-se um projeto reflexivo e contestador. O personagem do anti-herói não poderia ser inofensivo nem admirável como um herói clássico, mas um transgressor em ação e em relação com os espectadores e espectadoras.

O primeiro canovaccio ${ }^{4}$ da peça surgiu desses elementos: anti-herói, empatia,

${ }^{4}$ Roteiro de ações, instrumento utilizado na Commedia Dell'Arte sobre o qual os atores improvisavam

GARGIONE, Denisson Beretta; GRAEFF, Lucas. Bricolagens khaótica, memória social e engajamentos em Sr. Clandestino. Revista da FUNDARTE. Montenegro, p.01-21, ano 20, ㄲo 43, outubro/dezembro de 2020.

Disponível em: http://.seer.fundarte.rs.gov.br/index.php/revistadafundarte/index $>20$ de dezembro de 2020. 


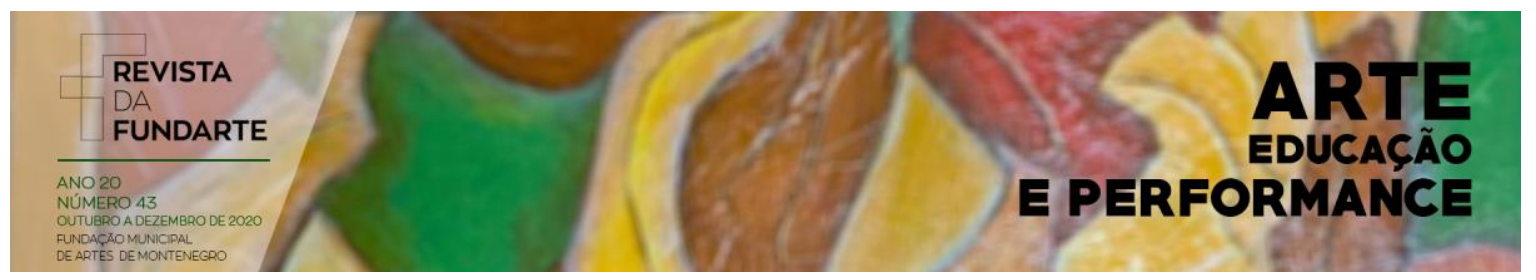

engajamento do público. Assim, escrevemos sobre a chegada de um cientista de outra dimensão, e sua intenção de acionar uma bomba para destruir a dimensão alternativa - a que nós vivemos - mas que poderia ser impedido por uma autômata, uma espécie de robô chamada Parody, que o acompanharia. Esse canovaccio rimava com o primeiro episódio da série animada Rick and Morty (2013), que repete a mesma estrutura no seu prólogo.

O primeiro canovaccio tornou-se a nossa cena de abertura, uma carta de apresentação de um anti-herói anárquico e imoral. A construção desta cena, em especial, foi pensada por meio do grammelot $^{5}$, uma ferramenta a mais para a provocação imediata do público. O estranhamento inicial, para nós, teria por consequência provocar uma tensão entre antipatia e racionalidade.

Seguimos preparando nossos canovaccios seguindo o fluxo de nossas ideias e descobertas. Elaborávamos uma linha ou tensão dramática, que era colocada à prova em cena, a partir do personagem atuando sobre o problema, buscando soluções. O material foi surgindo do ator principal e de seu personagem, mas sempre se coletivizava pelas encenações junto à equipe, trocas de ideias e uso de um caderno de bordo e de gravações audiovisuais. Assim, o material ia e vinha entre leituras do mundo, escrita, diálogos e encenações. Nosso primeiro público, nesse sentido, era a própria equipe de trabalho. Todos participamos na leitura dos primeiros textos e das primeiras encenações de Sr. Clandestino. Nós discutimos o material, propomos alternativas e realizamos, juntos, mudanças substanciais: Lauren Hartz, na produção, contrarregragem, ensaiadora e fazendo a voz da Parody; Marcos Cardoso, assumindo a direção, em especial a direção de ator; Rodrigo Ferreira, com a composição e direção musical; e Paola Zanette, como figurinista.

\section{RUÍDOS E FLUTUAÇÕES}

Em seu livro "Caos Dramaturgia", Rubens Rewald coloca elementos que costumam acompanhar a construção dramatúrgica e que são incorporados em

a cena valendo-se de seus repertórios artísticos individuais. (Berthold, 2000). No nosso trabalho, o canovaccio é um instrumento para a criação cênica, e não o produto final da dramaturgia.

5 Jogo arbitrário de sons que constroem um discurso a partir da performance do ator.

GARGIONE, Denisson Beretta; GRAEFF, Lucas. Bricolagens khaótica, memória social e engajamentos em Sr. Clandestino. Revista da FUNDARTE. Montenegro, p.01-21, ano 20, ㄲo 43, outubro/dezembro de 2020.

Disponível em: http://.seer.fundarte.rs.gov.br/index.php/revistadafundarte/index $>20$ de dezembro de 2020. 


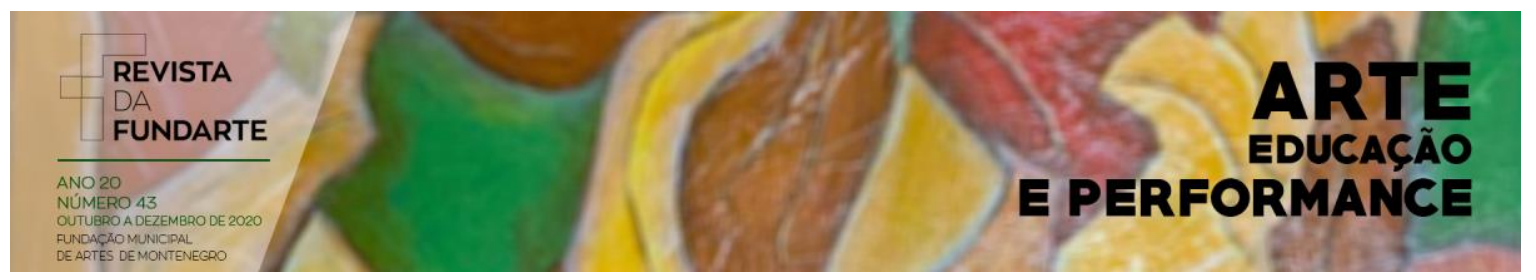

novas auto-organizações da estrutura. Rewald aponta o "ruído" e a "flutuação" como elementos significativos do processo. Enquanto o ruído seria "todo evento aleatório à história do processo, uma informação que a priori não faz parte do programa, sendo que sua ocorrência causará sempre um efeito imprevisível" (REWALD, 2005, p. 22), as flutuações já não são "necessariamente aleatórias" como "a reação da plateia, ou então a crítica de um jornalista".

\begin{abstract}
De início considerarei o processo como de auto organização a partir do "ruído" ou da "flutuação". Em que bases posso afirmar isso? O alimento vital do processo é a informação, seja escrita, verbal, visual ou sonora. É por meio da troca de informações que os diferentes profissionais (dramaturgo, diretor, atores, cenógrafo, figurinista, iluminador, sonoplasta, produtor) articulam o seu trabalho dentro da peça. Em tal fluxo de informações, a flutuação ou o ruído são fundamentais como forma de evolução, pois obriga o processo a se rearticular a partir dessa nova informação, criando novas possibilidades de resposta do processo (em termos de texto, encenação, interpretação). A ordem é perturbada pela desordem, originando discussões, reelaborações, equívocos, soluções e descobertas. Essa perturbação obriga o processo a se reorganizar num novo patamar. (REWALD, 2005, p.22).
\end{abstract}

Nesta perspectiva, no início da composição do trabalho, quando já tínhamos o esboço de grande parte da dramaturgia decupada e organizada, apresentamos o conceito da cena 2 (que ainda estava em processo de elaboração) para a equipe. A cena consistia na construção de uma rememoração do protagonista e desvelava o momento em que, trabalhando em uma indústria de refrigerante, ele rompia sua tolerância e tornava-se o anti-herói.

Este momento, além de ser importante do ponto de vista dramatúrgico, pois apresenta ao público a gênese do herói, também traz uma crítica ao processo industrial que aliena os trabalhadores em relação ao produto de seu trabalho. Todos que ouviam minha explicação sobre a cena foram rompidos pela fala de Lauren Hartz, que disse "Coca-Cola”. Imediatamente o compositor Rodrigo pegou o violão e dedilhou parte do jingle clássico do tema. O debate circulou sobre o slogan "abra a felicidade", talvez a frase mais emblemática da Coca-Cola dos últimos anos, e seguimos discutindo sobre a dependência da cafeína e os males dos refrigerantes. Um poema curto de Mário Quintana (2013) veio à baila:

GARGIONE, Denisson Beretta; GRAEFF, Lucas. Bricolagens khaótica, memória social e engajamentos em Sr. Clandestino. Revista da FUNDARTE. Montenegro, p.01-21, ano 20, ㄲo 43, outubro/dezembro de 2020.

Disponível em: http://.seer.fundarte.rs.gov.br/index.php/revistadafundarte/index $>20$ de dezembro de 2020. 


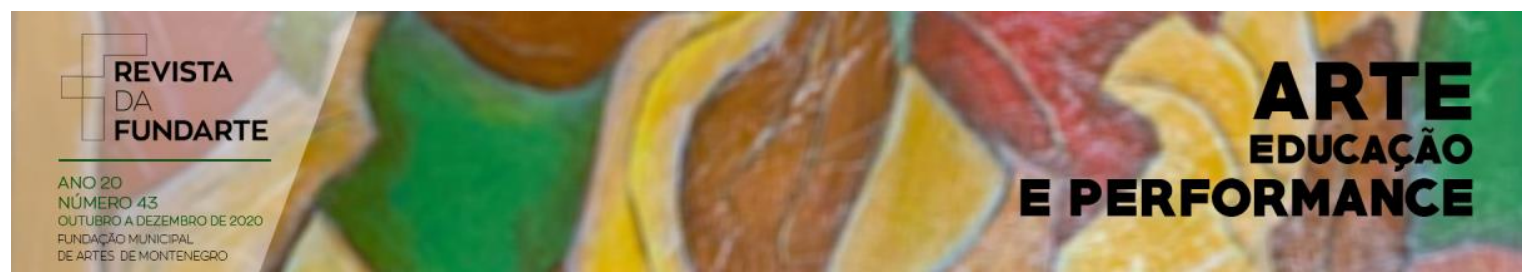

Em todos os aeródromos, em todos os estádios, no ponto principal de todas as metrópoles, existe - quem é que não viu? - aquele cartaz...

De modo que, se esta civilização desaparecer e seus dispersos e bárbaros sobreviventes tiverem de recomeçar tudo desde o princípio - até que um dia também tenham os seus próprios arqueólogos - estes hão de sempre encontrar, nos mais diversos pontos do mundo inteiro, aquela mesma palavra.

E pensarão eles que Coca-Cola era o nome de nosso Deus! (QUINTANA, 2013, p. 272).

Logo realizamos anotações que levaram à elaboração de uma cena cômicodramática que, além de apresentar o surgimento do protagonista como revolucionário e anti-herói, traziam uma crítica à alienação do trabalho diante da produção industrial, estabelecendo uma relação principal como um dos maiores símbolos do livre mercado, a Coca-Cola. Era o primeiro grande ruído que impactou o trabalho e criou uma grande flutuação de composição da cena.

Em outro momento, quando o texto já havia se completado e estava no segundo tratamento, discutíamos a cena 3 com o diretor Marcos Cardoso, em especial sobre a "Pistola da Empatia", utilizada pelo personagem principal. No texto Sr. Clandestino informa: "Essa é uma pistola de empatia. Ela rompe as barreiras coléricas da psique e deixa o indivíduo apto para perceber o outro. Em dimensões decadentes sempre falta empatia.". Marcos comentou que havia conversado sobre o espetáculo com sua esposa, e como ele havia gostado do conceito desta arma, cuja inspiração havia sido a Arma do Ponto de Vista do livro "O Guia do Mochileiro das Galáxias"

\begin{abstract}
A Arma do Ponto de Vista faz precisamente o que o seu nome diz. Ou seja, se você apontá-la para alguém e puxar o gatilho, a pessoa instantaneamente verá as coisas pelo seu ponto de vista. Ela foi desenvolvida pelo Pensador Profundo a pedido de um grupo de donas de casa raivosas que, depois de muito brigar com os seus maridos, se encheram de sempre terminar as brigas com a frase "Você simplesmente não entende, não é? (ADAMS, 2016).
\end{abstract}

Contudo, diferentemente da obra de Adams (2016), em Sr. Clandestino, a Pistola da Empatia não tem uma ação coercitiva, o que a torna mais paradoxal. Nesse sentido, Marcos trouxe a sugestão de sua esposa: o protagonista poderia usar a arma contra si mesmo, visto que ele não estaria tendo paciência com as

GARGIONE, Denisson Beretta; GRAEFF, Lucas. Bricolagens khaótica, memória social e engajamentos em Sr. Clandestino. Revista da FUNDARTE. Montenegro, p.01-21, ano 20, ㄲo 43, outubro/dezembro de 2020.

Disponível em: http://.seer.fundarte.rs.gov.br/index.php/revistadafundarte/index $>20$ de dezembro de 2020. 


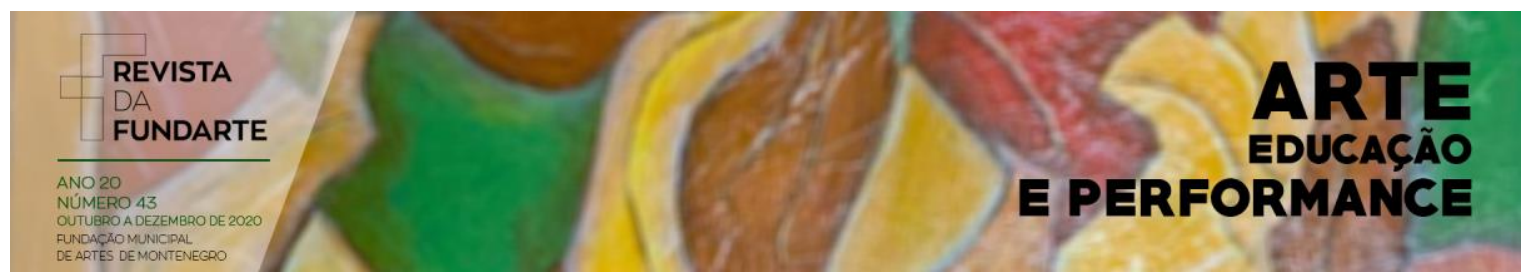

pessoas de nossa dimensão.

A Pistola da Empatia foi uma importante flutuação em nosso processo de criação e composição dramatúrgica. Esses e outros elementos "fluídos", que foram incorporados à tessitura dramática, provocaram bifurcações e alternações. Como escreve Rewald, "A todo momento construímos bifurcações imaginárias, propondo diferentes desenvolvimentos para a nossa vida; queremos mudar o nosso passado como a melhor forma de alterar o presente, quase sempre insatisfatório" (REWALD, 2005, p. 7).

\section{DECOMPOSIÇÕES: O PÚBLICO AGENTE DO CAOS}

Para dar mais vazão às flutuações e fluidificações do processo criativo, nós e a equipe do espetáculo optamos por realizar quatro ensaios abertos. Nós desejávamos um trabalho aberto, inconcluso, antes de experimentar as respostas do público. Assim, apresentamos, sucessivamente, diferentes partes da peça, trechos de algumas cenas, ou até mesmo cenas inteiras, mas não o espetáculo completo. As respostas do público nesses ensaios foram fundamentais. Como exemplo, já no primeiro ensaio aberto, uma das espectadoras falou que o anti-herói Sr. Clandestino parecia saído do filme "As Loucas Aventuras de James West6". Essa relação visual nos pareceu interessante e nós a retrabalhamos nos figurinos, no cenário e na dramaturgia.

De maneira geral, aliás, o público dos ensaios abertos destacou a visualidade do trabalho. A maioria não estava familiarizada com o gênero steampunk, que foi se impondo ao longo do trabalho criativo. O steampunk é uma estética celebrada, primeiramente, pela literatura que ganhou espaço em outras artes, em especial nas artes com apelo predominantemente plástico. Esse universo localiza-se historicamente no final do século XIX. A partir da Revolução Industrial, iniciada no final do século XVIII na Inglaterra, iniciou-se uma série de transformações sociais

\footnotetext{
${ }^{6}$ Comédia de ação americana que mistura faroeste com steampunk. Dirigido por Barry Sonnenfeld, estreou em 1999 e teve no elenco Will Smith e Kevin Kline como personagens principais.
}

GARGIONE, Denisson Beretta; GRAEFF, Lucas. Bricolagens khaótica, memória social e engajamentos em Sr. Clandestino. Revista da FUNDARTE. Montenegro, p.01-21, ano 20, no 43, outubro/dezembro de 2020.

Disponível em: http://.seer.fundarte.rs.gov.br/index.php/revistadafundarte/index $>20$ de dezembro de 2020. 


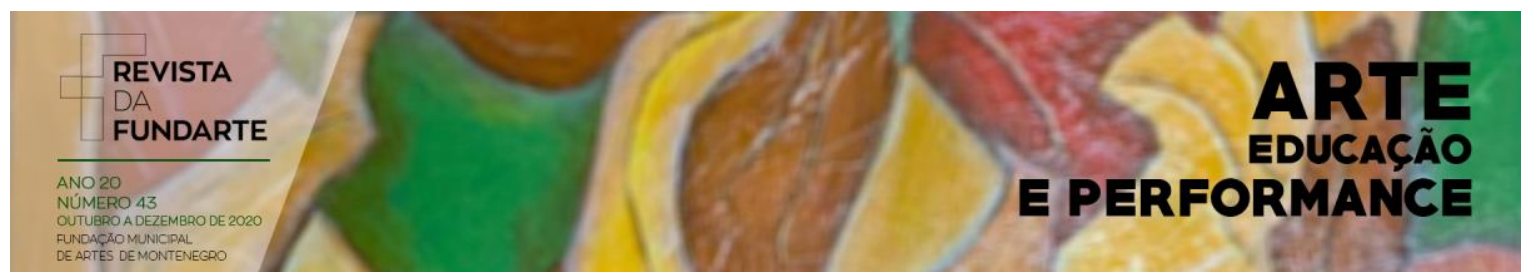

que estabeleceram um novo modo de pensar e (re)agir à sociedade que se transformava, grande parte devido as mudanças na produção e trabalho, que provocaram uma reavaliação dos papéis sociais mas, principalmente, pelas inovações tecnológicas que, através de invenções como o telégrafo, telefone e transporte a vapor, revolucionaram a compreensão da realidade social (SINGER, 2001).

O gênero steampunk encontra nesse período histórico a sua inspiração, mas há um hibridismo de forma. É como se o quadro sociocultural fosse furtado de seu momento histórico e projetado em um futuro distópico, "reciclando" suas possibilidades de desenvolvimento o tecnológico. Conforme Pegoraro (2012), a característica seminal de relação do steampunk com este período histórico, é o fato de ter se concretizado uma revolução tecnológica sem precedentes:

\begin{abstract}
A junção das palavras steam e punk deve-se ao fato de as histórias se passarem num tempo híbrido entre a Era Vitoriana e um futuro sob a ótica punk. A tecnologia a vapor (steam) é o que inspira grande parte das criações. Uma das justificativas por esse interesse deve-se ao fato de a utilização do vapor ter revolucionado as formas de produção e estar no cerne da Revolução Industrial do século XIX: uma era de grandes mudanças com novos modos de transporte e técnicas produtivas, além das descobertas científicas, medicinais e de armamentos. (PEGORARO, 2012, p. 393).
\end{abstract}

Em nosso trabalho, esse "tempo híbrido", próprio ao gênero steampunk, dialoga com a concepção de memória social como reconstrução inventiva e intempestiva de sentidos, aberta aos divertimentos da linguagem e da imaginação. Acreditávamos que o steampunk seria, estranhamente, familiar aos públicos, algo compatível com a ideia de um anti-héroi, viajante entre dimensões paralelas. A nossa surpresa foi em relação ao juízo estético que os diferentes públicos pronunciaram: em regra geral, o nosso visual era "antigo e tecnológico". De certa forma, o que se tem é uma reapropriação de feixes memoriais, por meio de elementos imaginários coletivos - uma espécie de potencialidade, uma memória "protética", isto é, ancorada em um futuro que não pôde existir.

Em outras palavras, a reação do público foi interpretada por nós como uma

GARGIONE, Denisson Beretta; GRAEFF, Lucas. Bricolagens khaótica, memória social e engajamentos em Sr. Clandestino. Revista da FUNDARTE. Montenegro, p.01-21, ano 20, ㄲo 43, outubro/dezembro de 2020.

Disponível em: http://.seer.fundarte.rs.gov.br/index.php/revistadafundarte/index $>20$ de dezembro de 2020. 


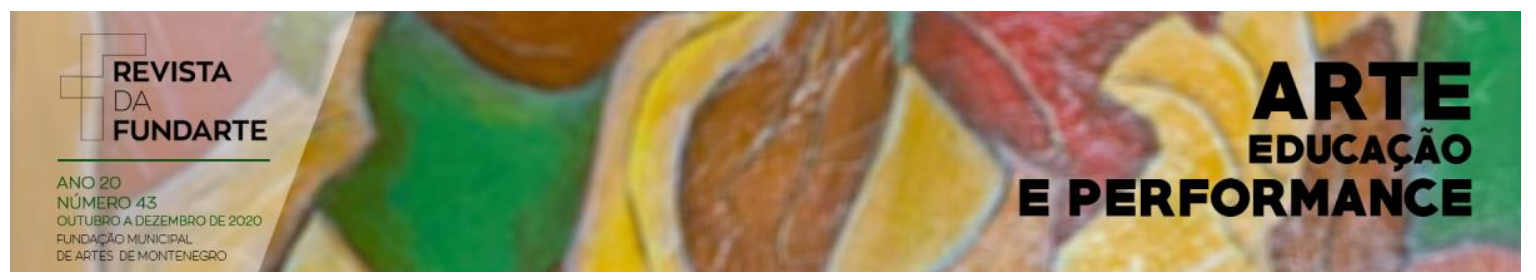

reapropriação de elementos de uma memória coletiva que falhou, mas que persiste na imaginação - a Belle Époque, o mal-estar da cultura punk e os sonhos de tecnocracia pós-industrial. Elementos que, em nossa proposta metodológica, foram pensadas para desencadear o engajamento do público, e praticadas como bricolagem cultural.

Os juízos, questionamentos e sugestões do público dirigiram-se também ao discurso "científico" do personagem. Nos ensaios abertos, o personagem insistia em não explicar suas origens ou o porquê de estar ali. Somada à dificuldade em compreender conceitos abstratos e mencionada de forma rápida, a "cientificidade" do Sr. Clandestino foi interpretada também como algo místico ou esotérico.

Estes apontamentos trouxeram para cena dois aspectos interessantes. Em primeiro lugar, a interferência direta sobre a dramaturgia gerou novas falas do protagonista dedicadas a explicar os conceitos sob qual ele operava. Em segundo lugar, mais humor: as tentativas reiteradas do Sr. Clandestino em explicar sua "ciência" a um público aparentemente ingênuo, tornaram-se um ponto forte da construção de um personagem irônico, rabugento e deprimido.

Por outro lado, a personalidade do personagem principal chamava a atenção do público jovem. Suas reflexões existencialistas sobre o mundo, o passado, o futuro e a ciência encontravam eco entre os adolescentes, que me questionaram diretamente qual seria a verdade sobre o que estava sendo dito pelo Sr. Clandestino. Como sugere Rewald (2005):

[...] era desejo do dramaturgo impregnar de ambiguidade as relações entre personagens. Nada seria muito explícito. Quanto maior o número de possíveis significados para uma cena, melhor. [...] Todas essas questões articulavam uma diretriz dramática que moldaria a construção do texto da peça. (REWALD, 2005, p. 25).

Para nós, diferentemente da peça Narrador, a qual o autor Rewald (2005) se refere no texto citado acima, Sr. Clandestino não intencionava o mesmo grau de ambiguidade. Ao menos, não de forma explícita. Buscava, por outro lado, mais possibilidades reflexivas, a partir da interpretação dos fatos, em especial, a partir da sua mente perturbada.

GARGIONE, Denisson Beretta; GRAEFF, Lucas. Bricolagens khaótica, memória social e engajamentos em Sr. Clandestino. Revista da FUNDARTE. Montenegro, p.01-21, ano 20, ㄲo 43, outubro/dezembro de 2020.

Disponível em: http://.seer.fundarte.rs.gov.br/index.php/revistadafundarte/index $>20$ de dezembro de 2020. 


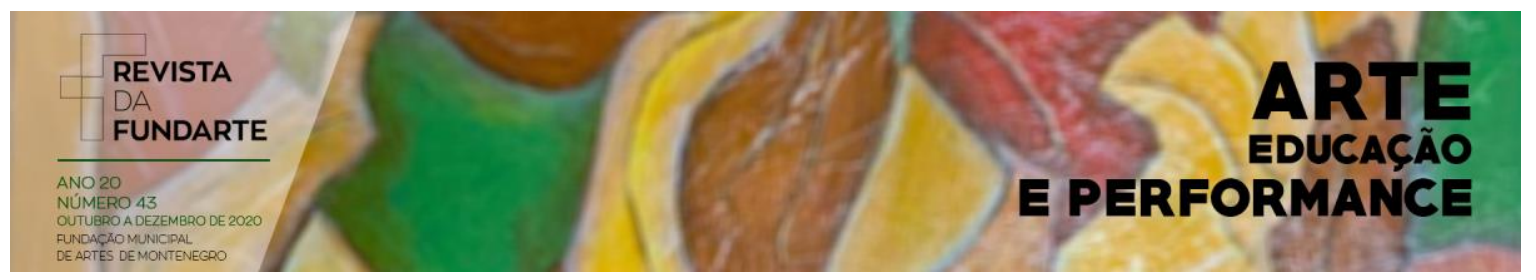

Por fim, o tema mais recorrente nas questões do público era o da bomba. Apresentar este artifício em cena e questionar, frequentemente, sua utilização (ou não) causava curiosidade. Nos ensaios abertos, porém, não apresentamos o desenlace da peça, a partir da decisão do público de acionar ou não a bomba. Por mais que a construção do espetáculo tivesse a participação do público em seu desenvolvimento, o que nos levou à flutuações e reescritas, a questão da "bomba" era uma bifurcação de roteiro necessária, e, sobretudo, tínhamos o interesse de deixá-la em aberto, em suspense, até a estreia da peça. Inspirávamos novamente em Rewald (2005) e em nossas memórias sociais:

O filme cinematográfico é um suporte essencialmente fechado, com raríssimos casos de experiências interativas. Entre elas podemos citar a de William Castle, diretor e produtor americano de filmes $B$ dos anos cinquenta e sessenta, na qual o público, por meio de cartazes com desenho de um dedo polegar, distribuídos no início da projeção, poderia escolher o final do filme Mr. Sardonicus, decidindo se o vilão deveria ou não morrer. Se a maioria dos cartazes levantadas pelo público mostrasse o polegar para baixo, tal qual numa arena romana de leões e cristãos, o projecionista exibiria o rolo com a morte do vilão. Se o polegar para cima prevalecesse, o rolo exibido salvaria a vida do bandido. (REWALD, 2005, p. 14).

O procedimento utilizado por Castle em seu filme "Mr. Sardonicus" foi uma estratégia objetiva e eficiente, mas nada sutil. No campo do teatro, o espetáculo "Ícaro" de Daniele Finzi, por exemplo, utilizava a participação do público dando-Ihe poder de decisão a partir da improvisação direta, cujo ator valia-se de seu repertório de clown, entretanto, o jogo focava na relação direta com um espectador. Almejávamos algo mais coletivo.

\section{O RUÍDO PIAF: EPIFANIA EM CENA}

As reações do público foram decisivas para a nossa metodologia. Porém, o mais importante ruído veio de um vídeo da interpretação de Louis Armstrong da canção La Vie en Rose. Visto por acaso, o vídeo nos mobilizou a buscar a voz "original" da canção - um original imaginado, desejado, mais que real. Pesquisando na internet, localizamos uma gravação de 1947 de Edith Piaf. Foi essa voz que nos marcou, enfim: já havíamos escutado diversas, mas desta vez sentimos uma

GARGIONE, Denisson Beretta; GRAEFF, Lucas. Bricolagens khaótica, memória social e engajamentos em Sr. Clandestino. Revista da FUNDARTE. Montenegro, p.01-21, ano 20, ㄲo 43, outubro/dezembro de 2020.

Disponível em: http://.seer.fundarte.rs.gov.br/index.php/revistadafundarte/index> 20 de dezembro de 2020. 


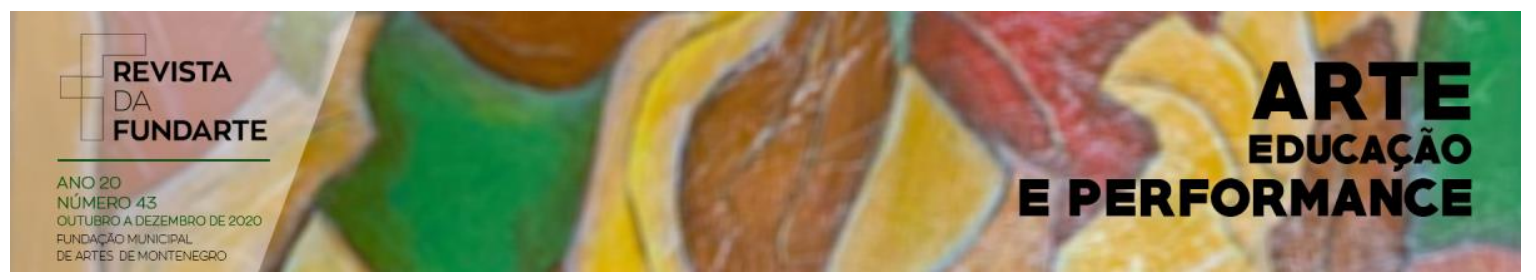

espécie de epifania. Era como se a versão de 1947 fosse aurática, no sentido benjaminiano - ainda que se tratasse de uma reprodução técnica. Ressentimos algo de novo. E decidimos incorporar a versão à peça a fim de compartilhar a epifania em cena.

Estruturamos a penúltima cena com o seguinte argumento, transcrito de um dos cadernos de campo: desesperado diante da fatalidade dessa dimensão e a iminente possibilidade de ter que explodi-la o Sr. Clandestino toca a música La Vie em Rose em seu trompete como uma busca de um toque de autenticidade, que revele no público que seus traços altruísmo e encantamento, únicas características que comprovadamente poderiam contrapor-se ao destino fatalista, e resgatar a fé social.

No espetáculo o Sr. Clandestino, La Vie en Rose aparece como um abrigo emocional, depois do confronto entre as rememorações do protagonista e a situação de conflito no presente, quando ele pega uma caixinha de música e toca a melodia, sem uma explicação prévia ou motivo aparente. Porém, este dispositivo, que a princípio pode estabelecer no espectador um caráter de ambientação da cena, ou um MacGuffin ${ }^{7}$, ganha expressão ao final do espetáculo, que fica evidente na fala do herói:

\begin{abstract}
O traço de humanidade se baseia na compreensão caridosa da vida, não numa postura ególatra, mas na essência: toda vida importa, a existência importa. Acalentar a dor do outro como um dos traços mais profundos de construção de identidade. A ciência não consegue operar nesta fé irracional, aí esta o caos, aí esta o combustível de nossa esperança. E pra isso só sei de uma maneira para encontrar este traço de forma imediata. É uma arte ímpar. Algo que rompeu as dimensões de forma, muito mais sutil do que a anomalia, e fez com que me reencontrasse em minha própria humanidade (para o público) espero que funcione com vocês... Parody, ligue os amplificadores!
\end{abstract}

Ao final da fala, La Vie en Rose entra em cena. Nossa expectativa é que a canção seja suficiente para retrabalhar a empatia entre o protagonista e os públicos. Agora, não se trata mais de julgar a dimensão em que vivemos e decidir pelo uso da bomba, mas de reencontrar a humanidade em Sr. Clandestino. Pensando a partir da

\footnotetext{
${ }^{7}$ Elemento que o protagonista persegue ao longo da narrativa ele demonstra pouca ou nenhuma explicação conclusiva.
}

GARGIONE, Denisson Beretta; GRAEFF, Lucas. Bricolagens khaótica, memória social e engajamentos em Sr. Clandestino. Revista da FUNDARTE. Montenegro, p.01-21, ano 20, ㄲo 43, outubro/dezembro de 2020.

Disponível em: http://.seer.fundarte.rs.gov.br/index.php/revistadafundarte/index $>20$ de dezembro de 2020. 


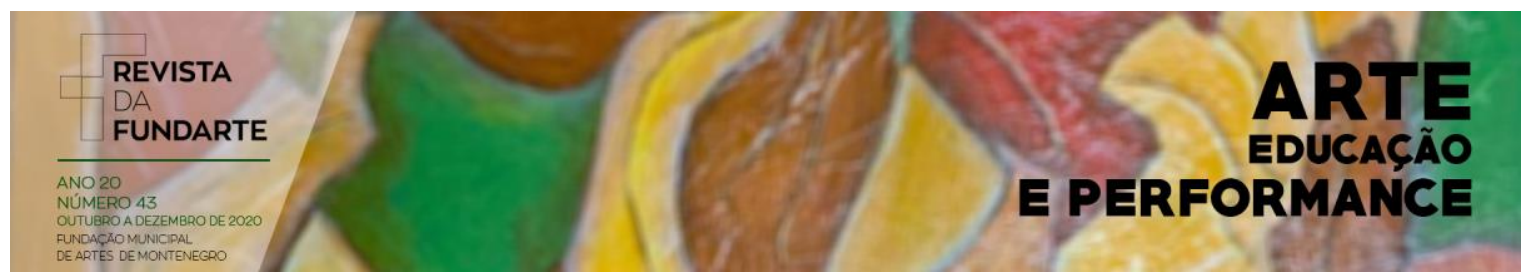

memória coletiva (Halbwachs, 2006), a intencionalidade deste momento da peça visa à efervescência geradora de vínculos sociais entre os indivíduos; ele ritualiza a união entre públicos e protagonista, gerando uma experiência compartilhada. As ações e falas de Sr. Clandestino transgridem, assim, o humor ácido e a desesperança do personagem - esses dois sentimentos convidativos de uma postura social-suicida - e derivam na Vie en Rose, nessa vida sem sentido, cinza, que se transveste de rosa ${ }^{8}$, de amor e de esperança.

Em Halbwachs (2006), nenhuma memória individual é auto-contida. Para se expressar, uma lembrança articula-se, necessariamente, em "correntezas de memória coletiva". Essas correntezas são enquadradas por elementos sociais, isto é, por representações coletivas, instituições e processos ritualizados. Sr. Clandestino apoia-se nessa hipótese fecunda para provocar as memórias individuais dos públicos e constituir um quadro comum de epifania. Em outras palavras, se frente à sua crise existencial o protagonista encontra sentido em uma obra de arte, por que os públicos não poderiam o mesmo?

Assim, Sr. Clandestino promove um movimento de trânsito entre as memórias de uma sociedade (amplamente criticada até os momentos finais da peça) e a possibilidade de adaptação às percepções construídas no público e norteadas pela performance de La Vie en Rose: "Se o que vemos hoje tivesse que tomar lugar dentro do quadro de nossas lembranças antigas, inversamente essas lembranças se adaptariam ao conjunto de nossas percepções atuais. Tudo se passa como se confrontássemos vários depoimentos." (HALBWACHS, p. 26, 2006).

\section{A REMEMORAÇÃO NA BRICOLAGEM KHAÓTICA}

Em Sr. Clandestino, a rememoração é uma trama dramatúrgica e uma ponte entre o personagem e os públicos. Rememoração não como uma prática de busca intencional de um passado ou de uma biografia, mas como "idas e vindas entre as

\footnotetext{
${ }^{8}$ La Vie en Rose é uma canção escrita e composta entre 1942 e 1947. Testemunha, portanto, o período "cinza" de ocupação nazista de Paris.

GARGIONE, Denisson Beretta; GRAEFF, Lucas. Bricolagens khaótica, memória social e engajamentos em Sr. Clandestino. Revista da FUNDARTE. Montenegro, p.01-21, ano 20, ㄲo 43, outubro/dezembro de 2020.

Disponível em: http://.seer.fundarte.rs.gov.br/index.php/revistadafundarte/index $>20$ de dezembro de 2020.
} 


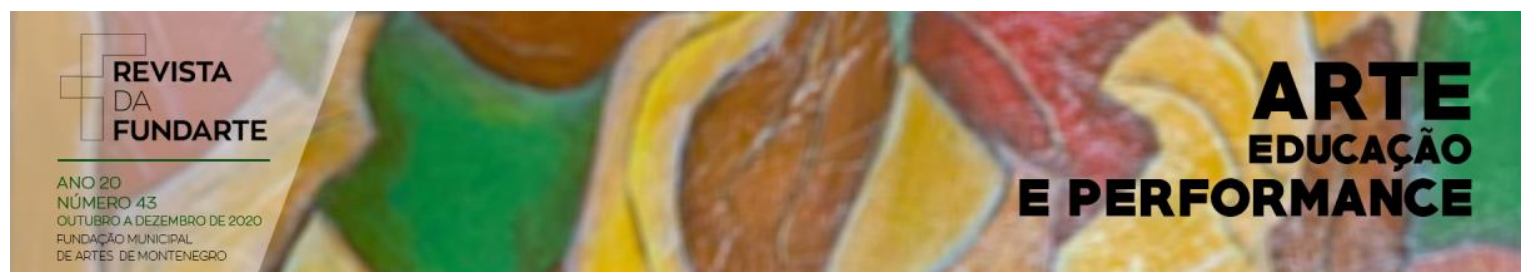

lembranças do passado e as inquietações do presente" (BERND, 2018). Dito de outra maneira, a rememoração em Sr. Clandestino dá-se como manifestação involuntária, como um eco ou ressonância de algo que aconteceu, que "rima" com uma vivência ordinária no presente.

$\mathrm{Na}$ primeira rememoração do personagem, algo completamente corriqueiro acontece. Em meio a uma discussão, Sr. Clandestino manifesta que está com sede e por consequência a autômata Parody responde "Seus níveis de hidratação estão baixos! Você deve beber algo...". A sentença "beber algo" dispara no protagonista a rememoração de quando trabalhava na manutenção da automação de uma fábrica de refrigerantes, especificamente, no momento da gênese de transformação do personagem, a circunstância derradeira que cercava 0 homem que era para alomorfia do homem que se tornou.

A rememoração, mediante artifício dramatúrgico, tem uma perspectiva benjaminiana:

O que se prenuncia nessas passagens é a memória perpetuadora do romancista, em contraste com a breve memória do narrador. A primeira é consagrada a um herói, uma peregrinação, um combate; a segunda, a muitos fatos difusos. Em outras palavras, a rememoração, musa do romance, surge ao lado da memória, musa da narrativa $(. . ; 211$; grifo de Benjamin apud OTTE, p. 212, 1996).

Apesar da ênfase na unidade, não é sob este foco que a rememoração em Benjamin deve ser reduzida. Esta individualização pode ser a consequência de diferentes associações. É um retorno, que permite presente e passado coexistirem diante de um episódio, conforme afirma Otte (1996). Contudo a rememoração do protagonista parece encontrar um viés mais psicanalítico:

Quando lembramos, freqüentamos acontecimentos que já transcorreram no tempo e nos provocaram algum traço ou marca. O recurso à memória não se dá apenas quando deliberadamente nos esforçamos por recordar, ele se faz presente no próprio processo perceptivo em que os traços são misturados às percepções, momento em que há o reencontro com um objeto (Freud, 1925/2007). Mas não só. Pode ocorrer das lembranças invadirem o espaço de nossa consciência sem que nos demos por isso, o caso paradigmático é o de Proust quando saboreia as madeleines e é atravessado pelas reminiscências de um tempo perdido

GARGIONE, Denisson Beretta; GRAEFF, Lucas. Bricolagens khaótica, memória social e engajamentos em Sr. Clandestino. Revista da FUNDARTE. Montenegro, p.01-21, ano 20, no 43, outubro/dezembro de 2020.

Disponível em: http://.seer.fundarte.rs.gov.br/index.php/revistadafundarte/index $>20$ de dezembro de 2020. 


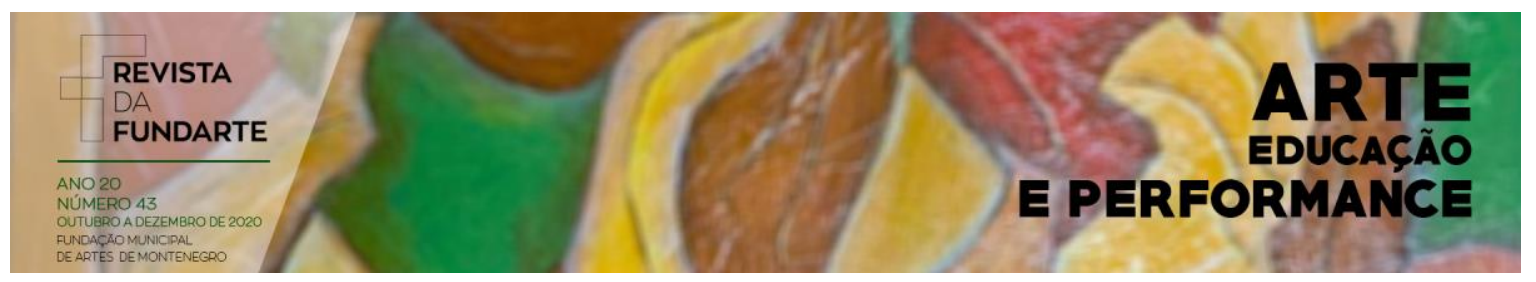

e singular. A essa modalidade de manifestação chamamos rememoração, sempre traz consigo uma situação definida e pessoalizada, nesse sentido são imagens menos socializadas, menos presas à ação presente e, portanto, mais distantes da atualização pela consciência, imagens semelhantes àquelas encontradas em nossas produções oníricas (Bosi, 1979/2006). (grifo dos autores, DOMICIANO; RODRIGUES, 2010).

As rememorações do Sr. Clandestino não são presas às ações presentes, mas são cruciais no desvendar a cortina sob sua identidade. Logo, diante da peça elas revelam mais sobre o presente, sobre quem o protagonista é, e estão menos preocupadas com quem ele foi. É a definição estabelecida pela dialética entre lembranças e esquecimentos coletivos (ASSMAN, 2011).

A rememoração do personagem é um processo que o causa ojeriza, pois é revelador. As lembranças encobertas traduzem uma cólera ou um medo sobre si, ou sobre a situação, que no enredo fica convenientemente mascarado, sob os efeitos das viagens interdimensionais. Conforme Assmann (2011) afirma, ao analisar aspectos na obra de Shakespeare, a cólera e o medo promovem o esquecimento, enquanto rancor e vingança estimulam a memória: "em prol da maturação da pessoa, e de acordo com as circunstâncias, pode ser igualmente importante esquecer lembranças e recordar coisas esquecidas".

O personagem, no momento da rememoração, não sofre seus efeitos, mas é ao terminar seu processo no presente, que sua percepção é impactada. 0 distanciamento entre aquele que foi e aquele que é diante do que ele deverá ser é a motivação de seus conflitos.

Mas a rememoração também funciona como refúgio no momento cujo Sr. Clandestino se inclina e revê. O recorte que o protagonista realiza sobre suas lembranças e o conhecimento que ele emprega ao observá-las, em certo aspecto romanceia a própria experiência, o livra da intimidação de sua realidade, e o tira dos ombros o fado da liberdade presente. Mesmo que seja por um curto prazo de tempo. Assmann traça aspectos semelhantes no personagem Ricardo II de Shakespeare:

Enquanto Ricardo se evade para o nível da recordação da narrativa, esquiva-se da pressão direta da realidade e ficcionaliza sua própria vida. Assíncrono consigo mesmo, divide-se em um conhecedor e um observador; como tal. Apressa os acontecimentos e os rememora como

GARGIONE, Denisson Beretta; GRAEFF, Lucas. Bricolagens khaótica, memória social e engajamentos em Sr. Clandestino. Revista da FUNDARTE. Montenegro, p.01-21, ano 20, ㄲo 43, outubro/dezembro de 2020.

Disponível em: http://.seer.fundarte.rs.gov.br/index.php/revistadafundarte/index $>20$ de dezembro de 2020. 


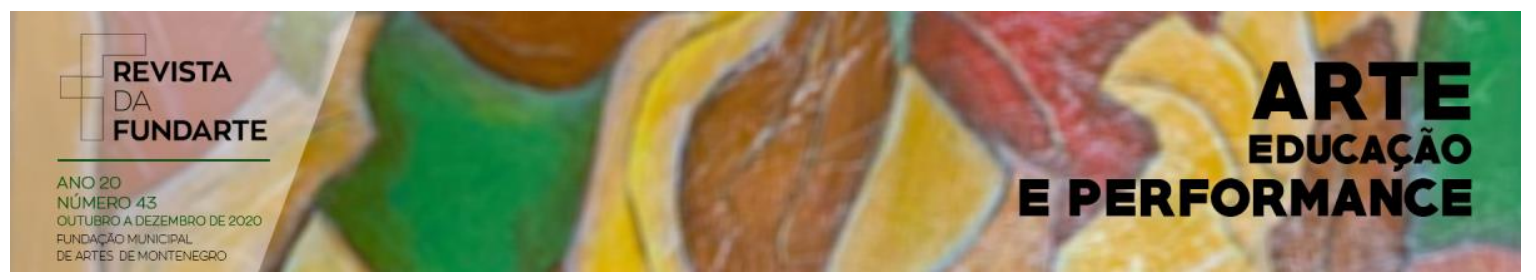

um estranho que os toma por concluídos. (p. 97, 2011).

Estes momentos do espetáculo desestabilizam o personagem porque, além do discurso identitário presente (que acabam por gerar conflitos existenciais), estabelecem uma relação de vínculo afetivo. Afeto e a memória se relacionam de forma consciente, entretanto a influência do primeiro sobre a segunda, escapa a moderação do herói. Logo, a rememoração tem muito mais pretensão de comprovar a ligação que o Sr. Clandestino conserva com o que passou, do que estabelecer uma visão preocupada, em uma veracidade objetiva. Conforme Assmann, ao tratar da autobiografia da escritora Mary Antin, ela observa que em seu texto há reflexões sobre suas recordações, lançando a máxima "Penso, sim, que suas observações não dizem respeito à estrutura da realidade, mas à das recordações" (ASSMANN, 2011, p. 273).

Entretanto, o afeto que desestabiliza o protagonista está ligado ao passado, no seu presente, ele se torna símbolo:

O que é afeto para as recordações da juventude é o símbolo para
recordações da velhice. Afeto e símbolo são estabilizadores de espécies
bem diferentes. A recordação que ganha a força de símbolo é
compreendida pelo trabalho interpretativo retrospectivo em face da
própria história de vida e situado no contexto de uma configuração de
sentido particular. (ASSMANN, p. 275,2011 ).

Há, portanto, uma reinterpretação do personagem do que é vivenciado. 0 afeto torna-se símbolo. Todavia, como um ciclo, há uma busca do protagonista pelo afeto, novamente como elemento estabilizador de si mesmo. A música La Vie en Rose tem este papel sempre após a rememoração, passível de ser vista como dispositivo do resgate de uma utopia juvenil, ou negação de uma maturidade amarga, mas ao final do espetáculo, estabelecendo uma proposição definitiva, como matéria de construção de um ideal simbólico: a da reinterpretação de uma memória coletiva.

\section{ATOS E PALAVRAS FINAIS: PARTILHA DO SENSÍVEL}

GARGIONE, Denisson Beretta; GRAEFF, Lucas. Bricolagens khaótica, memória social e engajamentos em Sr. Clandestino. Revista da FUNDARTE. Montenegro, p.01-21, ano 20, ㄲo 43, outubro/dezembro de 2020.

Disponível em: http://.seer.fundarte.rs.gov.br/index.php/revistadafundarte/index $>20$ de dezembro de 2020. 


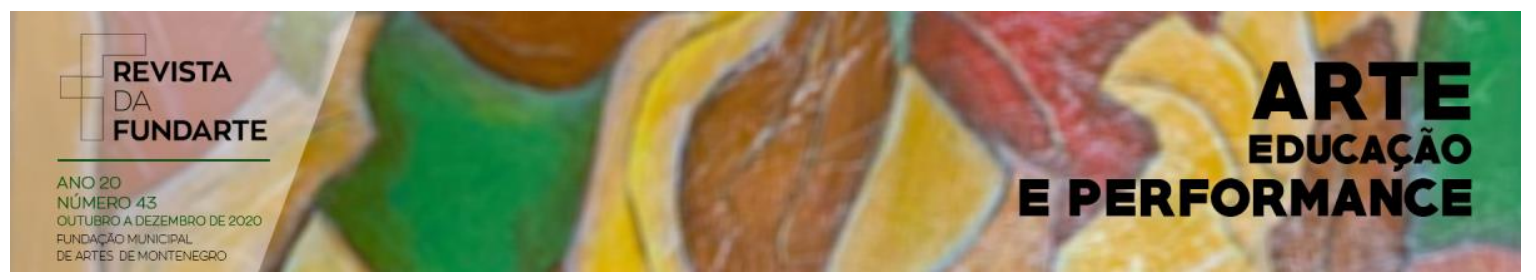

A arte realiza-se mediante seus públicos. Essa realização dá-se no presente do encontro do espectador/leitor/interprete, e a obra. Se para Canclini (1980), a formação social impacta diretamente a construção do espectador, o processo de produção e recepção da obra de arte não podem ser dissociados do meio social. Acontece que para muitos, o presente parece pontual, e o social, uma superfície; o imediato seria como um toque sem profundidade e o meio social, um palco sem bastidores ou platéia - e, sobretudo, sem a densidade das correntezas da memória, que são como escreve o poeta, as consciências inscritas no tempo.

Em nossa pesquisa, procuramos bricolar com as correntezas da memória em suas dimensões sensíveis e imaginárias, e engajar os públicos na construção do espetáculo Sr. Clandestino. De partida, pensávamos em promover a interação das pessoas - efeito que está na moda, em particular quando mediados por tecnologias da comunicação digital. Ao longo do processo, porém, o que mais nos valeu foram as reinterpretações das "intervenções" do público, na construção dramatúrgica e performática.

Por intervenções, porém, não tratamos apenas as respostas imediatas dos públicos durante os ensaios abertos. Os públicos estiveram conosco ao longo de todo o processo: ausentes fisicamente na maior parte do tempo, eles nos habitavam através das correntezas de memória coletiva. Nossas rememorações são as deles ainda que, em retorno, não saibamos se suas lembranças são da mesma natureza das que nós mesmos lembramos.

A memória social é, para nós, enigmática. É essa busca incessante e existencialmente recomeçada por causalidades formais e materiais. Mas em que consiste a matéria e suas formas? E como elas se imbricam e se "causam" (isto é, conversam entre si)? Não sabemos. Mas bricolamos com o enigma e, por meio de processos de criação dramatúrgica e performática, vivemos dos engajamentos com nossos públicos, com nossas memórias e com a existência mesma da vida, em suas sensibilidades e imaginações.

Como nomear esses engajamentos, afinal? Talvez como "partilha do sensível". Como escreve Jacques Rancière:

GARGIONE, Denisson Beretta; GRAEFF, Lucas. Bricolagens khaótica, memória social e engajamentos em Sr. Clandestino. Revista da FUNDARTE. Montenegro, p.01-21, ano 20, ㄲo 43, outubro/dezembro de 2020.

Disponível em: http://.seer.fundarte.rs.gov.br/index.php/revistadafundarte/index $>20$ de dezembro de 2020. 


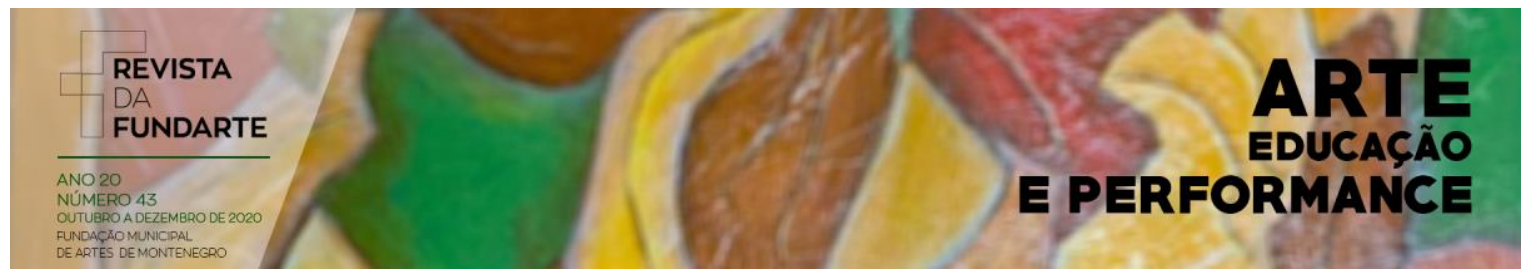

Partilha significa duas coisas: a participação em um conjunto comum e, inversamente, separação, a distribuição em quinhões. Uma partilha do sensível é, portanto, o modo como se determina no sensível a relação entre um conjunto partilhado e a divisão de partes exclusivas. (RANCIĖRE, 1995, p. 7).

A partilha estabelece a compreensão dos conjuntos e das partes. Rancière propõe um conjunto das partes na formação de um regime das artes, cujo o caráter político é inalienável. Este regime envolve o regime ético (que se relaciona com as práticas cidadãs, buscando a proposição de intencionalidade e objetivo em uma perspectiva política), o regime poético (refere-se ao gênero, estilo, aquilo que constitui constatação da arte), e por último o mundo estético (estabelece o modo sensível de consumo da arte, como produção distinta, ímpar e como rompimento e novas sensibilizações).

A "partilha do sensível" é, afinal, a consagração da arte e da criação em espaços e tempos de mediação partilháveis. É no encontro das correntezas da memória e das idiossincrasias individuais, que partilhamos nossa existência sensível. Nosso trabalho, neste espetáculo, é uma busca pelo sensível. Ou como escreveu o poeta Álvaro de Campos:

Sentir tudo de todas as maneiras,

Viver tudo de todos os lados,

Ser a mesma coisa de todos os modos possíveis ao mesmo tempo,

Realizar em si toda a humanidade de todos os momentos

Num só momento difuso, profuso, completo, longínquo ${ }^{9}$.

\section{Referências:}

ADAMS, Douglas. O Guia Definitivo do Mochileiro das Galáxias. São Paulo: Arqueiro, 2016.

ARISTOTELES. Poética. Lisboa: Fundação Calouste Gulbenkian, 2004.

BERND, Zilá. La persistance de la mémoire. Les romans de l'antériorité et leurs modes de transmission intergénérationnelle. Saint-Denis, France, 2018.

\footnotetext{
9 Trecho do poema Passagem das Horas de Álvaro de Campos, heterônimo de Fernando Pessoa
}

GARGIONE, Denisson Beretta; GRAEFF, Lucas. Bricolagens khaótica, memória social e engajamentos em Sr. Clandestino. Revista da FUNDARTE. Montenegro, p.01-21, ano 20, ㄲo 43, outubro/dezembro de 2020.

Disponível em: http://.seer.fundarte.rs.gov.br/index.php/revistadafundarte/index $>20$ de dezembro de 2020. 


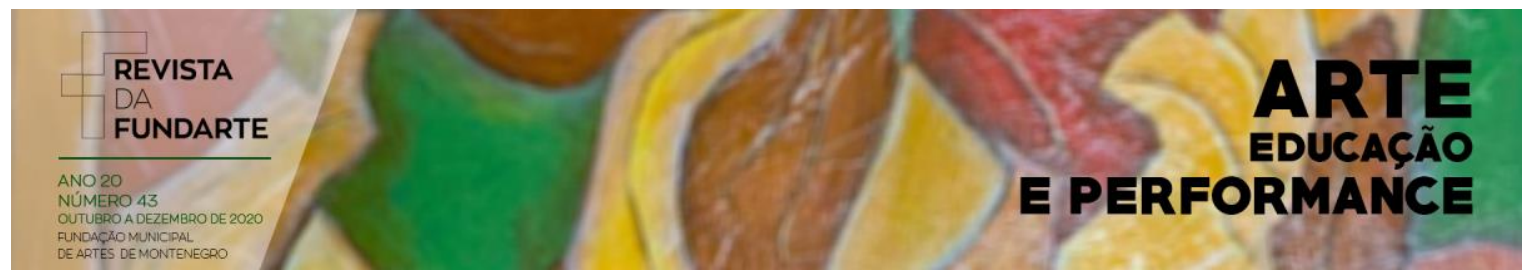

BRECHT, Bertold. Teatro Completo em 12 volumes. Vol. 6. Rio de Janeiro: Paz e Terra, 1991.

CANCLINI, Néstor Garcia. A socialização da Arte-Teoria e Prática na América Latina. São Paulo, Cultrix, 1980.

CAMPBELL, J. O poder do mito. São Paulo: Palas Athena, 1990.Rodrigues, 2010.

GRAEFF, Lucas. Patrimônio, memória e intencionalidade. Revista Confluências Culturais, 2016, n. 5, v. 2, pp. 177-189.

\section{Antropologia de Equipamentos Culturais: Adesão Situacional.} Morpheus, v. 10, n. 18, pp. 53-75, 2019.

HALBWACHS, Maurice. A memória coletiva. São Paulo: Centauro, 2006.

MITCHELL, J. The Rise of the Anti Hero: Why the characters in TV and movies we love most are the ones with fatal flaws. Relevant Magazine, 2013. Disponível em: <http://www.relevantmagazine.com/culture/tv/rise-anti-hero>. Acesso em: 02 fev.2019.

OTTE, Georg. Rememoraçao e Citaçao em Waller Benjamin. Revista de Estudos de Literatura, v.4, p. 211-223, out.1996. Disponível em: <http://www.periodicos.letras.ufmg.br/index.php/aletria/article/download/1145/1247>. Acesso em 20 jul. 2018.

PEGORARO, Éverly (2012). Steampunk: as transgressões temporais negociadas de uma cultura retrofuturista. Cadernos de Comunicação, v. 16, p. 389-400. Disponível em: <https://periodicos.ufsm.br/ccomunicacao/article/view/8236>. Acesso em 23 mar. 2019.

QUINTANA, Mario. Caderno H. Rio de Janeiro: Objetiva, 2013.

RANCIÈRE, Jacques. A partilha do sensível. Estética e política. São Paulo: EXO experimental/Editora 34, 2009.

REWALD, Rubens. Caos Dramaturgia. São Paulo: Ed. Perspectiva, 2005.

SINGER, Ben. Modernidade, hiperestímulo e o início do sensacionalismo popular. In: CHARNEY, Leo; SCHWARTZ, Vanessa (orgs.). O cinema e a invenção da vida moderna. São Paulo: Cosac \& Naif, 2001, p. 95-124.

GARGIONE, Denisson Beretta; GRAEFF, Lucas. Bricolagens khaótica, memória social e engajamentos em Sr. Clandestino. Revista da FUNDARTE. Montenegro, p.01-21, ano 20, ㄲo 43, outubro/dezembro de 2020.

Disponível em: http://.seer.fundarte.rs.gov.br/index.php/revistadafundarte/index $>20$ de dezembro de 2020. 